\title{
Fish fecal pellets are a source of minerals for inshore reef communities*
}

\author{
Gill G. Geesey ${ }^{1}$, George V. Alexander ${ }^{2}$, Richard N. Bray $^{3}$ and Alan C. Miller ${ }^{3}$ \\ ${ }^{1}$ Department of Microbiology, California State University, Long Beach, California 90840, USA \\ ${ }^{2}$ Laboratory of Biomedical and Environmental Sciences, University of California, Los Angeles, California 90024, USA \\ ${ }^{3}$ Department of Biology, California State University, Long Beach, California 90840, USA
}

\begin{abstract}
Fecal pellets of temperate and tropical reef fishes of the genus Chromis contained high concentrations of minerals, many of which are considered 'essential' for organismic growth. The concentrations of most elements were substantially higher in the feces than in undigested food recovered from the stomach. Large numbers of feces-associated bacteria, apparently derived from the gut microbial population, may have contributed to the high phosphorus levels in fresh feces. Phosphorus flux to inshore reefs via defecation of fecal pellets by the blacksmith $C$. punctipinnus in nocturnal shelters was comparable to estimates of phosphorus transport through surface waters by sinking zooplankton feces. Resistance of fecal pellets to degradation during long-term in situ incubation in nocturnal shelters suggests that bacteria do not play a significant role in controlling accumulation of fish feces on the reef.
\end{abstract}

\section{INTRODUCTION}

Understanding of the pathways of elemental transfer in the marine environment is one of the basic goals of oceanographic research. The role of particulate matter in the movement of nutrient and trace elements from surface to deep water or bottom sediments has been demonstrated in a number of instances (Menzel and Goering, 1966; Biship et al., 1977; Lal, 1977). Sinking fecal pellets of zooplankton have been shown to be an important vehicle for transporting a variety of elements through the water column (Small and Fowler, 1973; Fowler, 1977; Urrere and Knauer, 1981). Very little information exists, however, on the contribution of fish feces to element cycling.

Recently, Robison and Bailey (1981) presented evidence indicating that midwater fish fecal matter represent a major source of organic transfer between pelagic and benthic communities. From excretion studies, Bray et al. (1981) estimated that blacksmith Chromis punctipinnis imported approximately $8 \mathrm{~g}$ of carbon $^{-1}$

\footnotetext{
- Contribution 31 of the Southern California Ocean Studies Consortium

- Contribution 84 of the Catalina Marine Science Center, University of Southern California
}

$\mathrm{m}^{-2} \mathrm{~d}^{-1}$ to nocturnal shelters on rocky reefs off southern California. Although fecal pellets were found on the bottom of the shelters, they did not accumulate with time.

Reef fishes have been shown to feed on each other's feces (Robertson, 1982). Demersal zooplankton that emerge from sandy substrates at night may also feed on fish feces deposited in reef crevices (Hamner, 1981). Most nutritional studies of feces as a food source for marine organisms, however, have focused on their carbon and nitrogen content and, in some instances, on their protein, carbohydrate, and lipid composition (Johannes and Satomi, 1966; Robison and Bailey, 1981; Madin, 1982). In addition to the 'bulk' elements, there are likely to be significant levels of other essential elements in fish fecal material. Micronutrients such as phosphorus and silicon and numerous nanonutrients such as copper, iron, manganese, zinc, nickel, and chromium may also be important in establishing the suitability of feces as a food source for detritivores. To our knowledge, there is no information on the levels of micronutrients or nanonutrients in feces excreted by marine teleosts in the marine environment.

This paper presents concentration data for a variety of elements (many of which are required for growth) recovered from the feces of important reef fish of the genus Chromis. Species of Chromis were chosen for 
this study because their documented behavior of feces excretion in nocturnal shelters facilitates the estimation of allocthonous nutrient transport to inshore reefs.

\section{MATERIALS AND METHODS}

\section{Feces collection and processing}

Blacksmith Chromis punctipinnis were obtained from nocturnal shelters along the rocky bottom $(10 \mathrm{~m}$ depth) off Santa Catalina Island, USA, $35 \mathrm{~km}$ southwest of Los Angeles during July 1981. Brown chromis Chromis multilineatus were collected at the head of the Salt River Submarine Canyon off St. Croix, US Virgin Islands, at a depth of approximately $15 \mathrm{~m}$. All fish were collected at dusk by SCUBA with the aid of the anesthetic quinaldine and immediateiy placed in 201 plastic buckets with lids that were fitted with $1 \mathrm{~mm}$ netting to allow water exchange. Each bucket contained a $1 \mathrm{~cm}$ plastic grid suspended approximately $10 \mathrm{~cm}$ off the bottom. This feature minimized disruption of the feces once they sank to the bottom. The buckets, which contained from 1 to $10 \mathrm{fish}$, were anchored at the collection site. At dawn the following morning ( 7 to $8 \mathrm{~h}$ after collection) the fish were released and the buckets containing fecal pellets excreted by the fish during the night were brought to the surface. The intact pellets were transferred to GF/C filters with clean Teflon-coated forceps and either dried to constant weight at $60^{\circ} \mathrm{C}$ or transferred to diffusion chambers and placed on the bottom in nocturnal shelters.

Diffusion chambers were used to determine whether the elemental composition of the fecal pellets was affected by exposure to seawater or microorganisms. The diffusion chambers were similar to those described by Fliermans and Gordon (1977), consisting of $45 \mathrm{~mm}$ diameter Plexiglas cylinders enclosed at each end by polycarbonate membranes $(0.2 \mu \mathrm{m}$ pore size, Nuclepore Corp.) with 2 sampling ports sealed with neoprene septa on the side. Feces ( 3 to $4 \mathrm{~g}$ wet weight) placed inside the chambers containing filtersterilized seawater were thus protected from physical disturbances while incubating on the sea floor but still exposed to seawater in constant exchange with the external environment. Free exchange of dissolved substances across the membranes was demonstrated by loading separate chambers with ammonium chloride and Blue Dextran (MW, $2 \times 10^{6}$ daltons), placing them in nocturnal shelters, and following the diffusion of these substances out of the vessels. Ammonia concentration was determined with Nessler's reagent (American Public Health Association, 1971). Blue Dextran concentration was determined by absorption at $620 \mathrm{~nm}$ using a spectrophotometer. The time required for each of these substances to achieve one-half $\left(t^{1 / 2}\right)$ their initial concentration in the chambers was $3.5 \mathrm{~h}$ and $140 \mathrm{~h}$, respectively.

Chambers containing the feces were retrieved at intervals and the particulate material transferred to $\mathrm{GF} / \mathrm{C}$ filters and dried to constant weight at $60^{\circ} \mathrm{C}$. Fecal particles were pulverized in an acid-washed glass tissue homogenizer and the powder stored in new polyethylene vials in a desiccator for subsequent analysis.

Stomach contents were obtained from fish captured at dusk. The undigested food was collected by dissection and excision of the stomach wall with a sterile scalpel blade. The material was squeezed through the excision onto a GF/C filter, dried, pulverized, and stored as described above.

\section{Elemental analysis}

Multielement analysis of the feces and stomach contents was carried out by optical emission spectrometry using the analytical scheme of Alexander and McAnulty (1981). Briefly, 3 to $7 \mathrm{mg}$ of pulverized solid was quantitatively weighed into a graphite electrode. The sample was then volatilized and excited in a DC arc and the resulting light, which contained the spectral lines of the various elements present, was separated into its components by a diffraction grating spectrometer. The intensity of each component wavelength was measured quantitatively by a separate photomultiplier. The net signal was obtained by subtracting various background components from the total signal. Interference from signals of atomic lines of other elements in the sample was corrected for by analyzing standards of the interfering element. An on-line computer was employed for the calculations, providing a concentration value for each of 26 to 29 elements included in the polychrometer array. When background and interferences were determined, the sensitivity was limited to 0.1 to $1.0 \mathrm{\mu g} \mathrm{g}^{-1}$ for most elements. For zinc and phosphorus, the limit was 3 to 5 and 50 to $80 \mu \mathrm{g} \mathrm{g}^{-1}$, respectively (Alexander and McAnulty, 1981).

\section{Bacterial enumeration}

To estimate bacterial densities, samples of fecal pellets were transferred directly from the buckets at the surface to a sterile, tared aluminum weighing dish and the wet weight determined after removal of excess water with sterile pasteur pipetes. The contents of the dish were aseptically homogenized with $5 \mathrm{ml}$ of filtersterilized seawater in a micro-container (Eberback 
Corp.). The homogenate was serially diluted in filtered seawater and $0.5 \mathrm{ml}$ of a $100 \mu \mathrm{g} \mathrm{ml}^{-1}$ filter-sterilized aqueous solution of 4'6-diamidino-2-phenylindole (DAPI) was added to each dilution to stain the bacteria. After $5 \mathrm{~min}, 0.5 \mathrm{ml}$ of a $50 \%$ glutaraldehyde solution was added to preserve the stained cells. Two-ml volumes of the appropriate dilution were aseptically filtered through a $0.2 \mu \mathrm{m}$ polycarbonate membrane and the trapped bacteria on the surface of the membrane enumerated by epifluorescence microscopy using a filter combination (Zeiss 48-77-02) optimized for DAPI fluorescence. Bacterial densities were estimated from counts made on 20 randomly chosen microscope fields delineated by an eyepiece gradicule. Dilutions were selected which produced 10 to 100 bacteria field ${ }^{-1}$. Bacterial densities were expressed on a dry weight basis after independent determinations of the dry weight : wet weight ratio $(0.15 \pm 0.05, \mathrm{n}=17)$ were made on the fecal pellets.

Intestinal contents, extruded through the anus by applying hand pressure to the sides of the captured fish, were processed in the same manner as the fecal pellets for bacterial density determinations.

\section{RESULTS}

\section{Nanominerals}

Nanomineral concentrations in fresh blacksmith feces recovered from buckets containing captive fish ranged from $16 \mu \mathrm{g} \mathrm{g}^{-1}$ dry weight for $\mathrm{Cu}$ to $7,170 \mu \mathrm{g}$ $\mathrm{g}^{-1}$ dry weight for Fe (Table 1). The concentrations of all elements tested were higher in fecal material than in undigested food removed from the gut (Table 1). In the case of $\mathrm{Pb}$, over 2,000 times greater concentrations were found in fresh fecal pellets than in gut material. Iron was also highly concentrated in the feces. The lowest concentration ratios were exhibited by $\mathrm{Zn}, \mathrm{Cu}$, and $\mathrm{Sr}$.

Fresh feces obtained from brown chromis in tropical waters contained lower concentrations of $\mathrm{Cr}, \mathrm{Fe}, \mathrm{Mn}$, $\mathrm{Si}$ and $\mathrm{Pb}$ but higher concentrations of $\mathrm{Cu}, \mathrm{Zn}$ and $\mathrm{Sr}$ than fresh blacksmith feces collected in temperate waters off southern California (Table 1). Lead and Fe were noticeably less concentrated in brown chromis fecal pellets. The large standard deviation in $\mathrm{Pb}$ concentration values, however, indicates possible contamination or a highly heterogeneous distribution of the metal in the feces.

In view of the rapid change in elemental concentrations of undigested food during passage from the gut of the fish into the surrounding seawater as feces, a study was conducted to evaluate the extent to which elements were adsorbed by the pellets from the seawater.

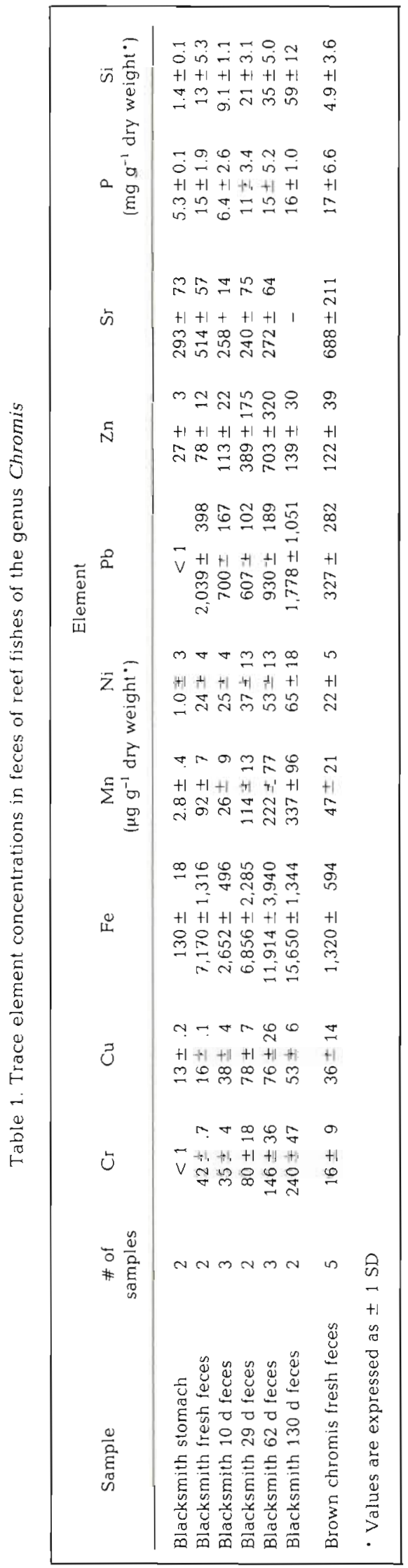


An increase in concentration of most trace elements was observed with time when fresh blacksmith feces were incubated in dialysis chambers that had been placed in the nocturnal shelters of the fish. Chromium levels increased approximately 6 -fold over a $130 \mathrm{~d}$ period (Table 1). The possibility of contamination of the feces by elemental leaching from the Plexiglas chamber was minimized by the constant exchange of water across the membrane. In fact, several of the elements ( $\mathrm{Fe}, \mathrm{Mn}, \mathrm{Pb}$, and $\mathrm{Sr}$ ) exhibited a substantial decrease in concentration during the first $10 \mathrm{~d}$ of feces incubation. Adsorption of elements from the surrounding seawater, therefore, did not appear to be sufficient to account for the concentration differences observed between stomach contents and fresh fecal pellets.

\section{Microminerals}

Phosphorus and silicon were present in similar concentrations in fresh blacksmith feces, contributing from 10 to $15 \mathrm{mg} \mathrm{g}^{-1}$ dry weight (Table 1). As in the case of nanominerals, undigested food removed from the guts of fish contained considerably lower concentrations of $\mathrm{P}$ and $\mathrm{Si}$ than fresh fecal pellets. The $\mathrm{P}$ concentrations in freshly collected brown chromis feces were comparable to that of blacksmith. Silicon concentrations were slightly lower in feces of brown chromis than blacksmith.

Incubation of the blacksmith feces in dialysis chambers maintained in nocturnal shelters for up to $130 \mathrm{~d}$ resulted in little change in fecal $P$ concentrations. However, fecal Si concentrations increased 4.5-fold during this period.

Table 2. Chromis spp. Bacterial densities associated with gut contents and fecal pellets

\begin{tabular}{|lcc|}
\hline \multicolumn{1}{|c}{ Sample } & $\begin{array}{c}\text { \# of } \\
\text { samples }\end{array}$ & $\begin{array}{c}\text { Cells g } \\
\text { dry weight }\end{array}$ \\
\hline $\begin{array}{l}\text { Blacksmith intestinal } \\
\text { contents }\end{array}$ & 2 & $3.5 \pm .14 \times 10^{10}$ \\
$\begin{array}{l}\text { Fresh blacksmith feces } \\
\text { Blacksmith feces after }\end{array}$ & 4 & $5.6 \pm 3.5 \times 10^{10}$ \\
9 d in chambers \\
$\begin{array}{l}\text { Blacksmith feces after } \\
30 \text { d in chambers } \\
\text { Brown chromis intestinal } \\
\text { contents }\end{array}$ & 2 & $6.3 \pm 1.2 \times 10^{10}$ \\
$\begin{array}{l}\text { Fresh brown chromis feces } \\
\text { Brown chromis feces after }\end{array}$ & 4 & $6.7 \pm .64 \times 10^{10}$ \\
5 d in chambers & 3 & $1.8 \pm .57 \times 10^{10}$ \\
$\cdot$\begin{tabular}{l} 
Values are expressed as $\pm 1 \mathrm{SD}$ \\
\hline
\end{tabular} & 2 & \\
\hline
\end{tabular}

\section{Bacteria}

Undigested food in the intestines of blacksmith and brown chromis contained very high densities of bacteria, ranging from $3.5 \times 10^{10}$ to $8.6 \times 10^{10}$ cells g $^{-1}$ dry weight, respectively (Table 2). Fresh Chromis fecal pellets contained bacterial densities similar to intestinal material. Blacksmith feces, incubated in shelters but protected in the chamber from the foraging activities of reef organisms, exhibited bacterial densities similar to fresh fecal pellets. In spite of the high bacterial densities, visual inspection indicated no noticeable physical change in fecal pellet consistency over $130 \mathrm{~d}$ of incubation. Bacterial density in fecal pellets of brown chromis decreased during $5 \mathrm{~d}$ incubation in the tropical waters off St. Croix (Table 2). The reason for the observed decrease is at present not known.

\section{DISCUSSION}

Chromis fecal pellets contained an abundance of minerals, many of which are considered 'essential' for growth of living organisms (Mertz, 1981). The mineral concentrations in fresh blacksmith feces collected in situ were generally different from the levels found in feces of marine invertebrates. Fowler (1977) found higher concentrations of $\mathrm{Cu}, \mathrm{Fe}, \mathrm{Mn}$, and $\mathrm{Zn}$ but lower concentrations of $\mathrm{Pb}$ and $\mathrm{Sr}$ in the feces of freshly caught euphausiids (Meganyctiphanes norvegica) than we detected in Chromis fecal pellets. The feces of algal-fed crabs (Pugettia producta), maintained under laboratory conditions, contained lower concentrations of $\mathrm{Cr}, \mathrm{Fe}, \mathrm{Pb}$, and $\mathrm{Zn}$ than Chromis feces (Booth and Knaver, 1972).

The enrichment of minerals in Chromis feces relative to gut contents suggests that mineral requirements are easily satisfied by the fish diets. This is consistent with studies on marine invertebrates (Booth and Knauer, 1972; Fowler, 1977) and indicates that like primary consumers, secondary consumers assimilate only a small portion of the total mineral content of their food. Alternatively, feces may be a more important route of disposal for some elements than for others. For instance, the higher concentrations of $\mathrm{Fe}$ in feces than in the food, gut contents, or body parts of organisms (Booth and Knauer, 1972; Fowler, 1977) could be due to specific elimination of Fe-containing bile pigments through the intestine. Further characterization of the concentration and flux of $\mathrm{Fe}$ and other elements that are concentrated in the feces of these fish should provide a better understanding of the mechanisms involved.

The concentrations of $\mathrm{Cu}, \mathrm{Fe}, \mathrm{Mn}, \mathrm{Ni}, \mathrm{Pb}, \mathrm{Zn}$, and $\mathrm{Sr}$ in stomach contents of the fish were very similar to the 
levels of these elements reported in zooplankton collected in Monterey Bay, California (Martin and Knauer, 1973). Since the latter are consumed by blacksmith (Hobson and Chess, 1976; Bray, 1981), trace element composition of the gut contents may be useful in food source identification.

Phosphorus levels in the fresh fish feces were similar to those found in feces of the omnivorous marine crustacean Palaemonetes pugio (Johannes and Satomi, 1966). The significance of the $P$ levels observed in the feces is more apparent when expressed in terms of carbon and nitrogen. Previous analysis of samples of fresh blacksmith feces collected from the fish at the same time and place as the samples reported here indicated an organic carbon content of $12.7 \%$ and a $\mathrm{C}: \mathrm{N} g$ atom ratio of 8:1 (Bray et al., 1981). On the basis of the $\mathrm{P}$ concentration obtained for fresh blacksmith feces (Table 1), the C:N:P ratio is $22: 2.8: 1$. This is much lower than that characteristic of living plankton (106:16:1) and indicates that the feces are enriched approximately 5 -fold in $P$ relative to the food of the fish which consists of drift zooplankton. Fecal pellets of gelatinous zooplankton exhibit a C:N:P ratio of 118-138:18.9-25:1 (Bruland and Silver, 1981) and ratios of suspended particles in upwelling areas have been reported to be 180:18:1 (Knauer et al., 1979). Others, however, have obtained ratios as low as 40:8:1 for particles in Antarctic waters where there is an abundance of $\mathrm{P}$ in the seston (Copin-Montegut and Copin-Montegut, 1978).

The $\mathrm{P}$ enrichment in blacksmith feces relative to zooplankton suggests that selective absorption of $\mathrm{C}$ and N-containing compounds may occur during food digestion by these fish. Alternatively, feces may be a more important route for $\mathrm{P}$ elimination than for that of $\mathrm{C}$ and $\mathrm{N}$.

The C:P ratio in bacteria can be as low as 30:1 (Atlas and Bartha, 1981). Our detection of very high densities of bacteria in fresh blacksmith and brown chromis fecal pellets is consistent with previous bacteriological data on gut and fecal flora of these fish (Ruby and Morin, 1979). The low C:P ratio exhibited by fresh Chromis feces may therefore have been at least in part due to the large numbers of bacteria present.

The data suggest that fresh blacksmith feces also serve as a rich source of Si. Using the previously determined carbon content indicated above, the feces exhibited a Si:C ratio of 0.043 . This value is higher than the average ratio $(0.016)$ obtained by Copin-Montegut and Copin-Montegut (1978) and Lisitzin et al. (1966) for particles obtained from regions of the Indian Ocean. Diatom and silicoflagellate remains, detected during microscopic examination of the fish feces, may have contributed to the silicon concentrations obtained in the pellets. Quartz, which has been shown to be a
Table 3. Comparison of elemental deposition rates on inshore reefs by blacksmith fecal pellets with elemental flux in water column via zooplankton feces

\begin{tabular}{|c|c|c|c|}
\hline \multirow[b]{2}{*}{ Element } & \multicolumn{3}{|c|}{ Flux $\left(\mu \mathrm{g} \mathrm{m}^{-2} \mathrm{~d}^{-1}\right)$} \\
\hline & Blacksmitha & $\begin{array}{l}\text { Zoop } \\
\text { offshore }\end{array}$ & $\begin{array}{l}\text { nton } \\
\text { nearshore }\end{array}$ \\
\hline P & 2,720 & - & - \\
\hline $\mathrm{Si}$ & 2,360 & - & - \\
\hline $\mathrm{Fe}$ & 1,300 & 37,599 & 26,400 \\
\hline $\mathrm{Pb}$ & 370 & 53 & 37 \\
\hline $\mathrm{Sr}$ & 93 & 122 & 86 \\
\hline $\mathrm{Mn}$ & 17 & 380 & 266 \\
\hline $\mathrm{Zn}$ & 14 & 1,492 & 1,045 \\
\hline $\mathrm{Cr}$ & 8 & - & - \\
\hline $\mathrm{Cu}$ & 5 & 354 & 249 \\
\hline $\mathrm{Ni}$ & 4 & 31 & 22 \\
\hline
\end{tabular}

a Elemental deposition rate based on importation of 181.5 $\mathrm{mg}$ dry weight feces $\mathrm{m}^{-2} \mathrm{~d}^{-1}$ (Bray et al., 1981)

b Mineral fluxes contributed by zooplankton fecal pellets estimated from elemental concentrations of euphausid fecal pellets ( $\mu \mathrm{g} \mathrm{g}^{-1}$ dry weight feces) as determined by Fowler (1977)

c Feces flux estimates calculated from total volumes (30.9 $\mathrm{mm}^{3}$ ) of zooplankton fecal pellets collected $100 \mathrm{~km}$ off Monterey, California at $35 \mathrm{~m}$ depth (Urrère and Knauer, 1981)

$\checkmark$ Feces flux estimates calculated from total pellets (120,000 specimens $\left.\mathrm{m}^{-2} \mathrm{~d}^{-1}\right)$ using an average pellet weight of $9.3 \mu \mathrm{g}$ (Dunbar and Berger, 1981). Samples collected in Santa Barbara Basin at $341 \mathrm{~m}$ depth

component of fecal pellets collected in sediment traps in coastal waters (Dunbar and Berger, 1981), may also have contributed to the silicon in the fish feces. It remains to be determined whether the silicon excreted in the blacksmith shelters is taken up by living cells such as benthic diatoms or incorporated into bottom deposits of the reef.

Mineral fluxes to inshore reefs via blacksmith fecal pellets were estimated from previous feces importation data (Table 3). It is important to recognize that the values represent a net influx to the reef community since the fish feed in the water column during the day (Bray, 1981). Furthermore, it is unlikely that the fecal pellets are subject to resuspension by water movement since they exhibit negative bouyancy (Bray et al., 1981) and the shelters are generally located in crevices in the reef.

Evaluation of the relative significance of mineral deposition by blacksmith is difficult since there is very little information on other mineral importation processes. Some comparisons can be made, however, with mineral flux mediated by particles sinking through the water column. The $2.7 \mathrm{mg} \mathrm{Pm}^{-2} \mathrm{~d}^{-1}$ imported as blacksmith feces to inshore reefs represents approximately $45 \%$ of the total P ( $\left.6 \mathrm{mg} \mathrm{P} \mathrm{m} \mathrm{m}^{-2} \mathrm{~d}^{-1}\right)$ transported 
from surface waters to a depth of $50 \mathrm{~m}$ by sinking particulate matter in an area of coastal upwelling (Knauer et al., 1979). Trace mineral deposition as blacksmith feces was generally lower than mineral fluxes computed for fecal pellets of zooplankton from the water column in sediment traps off the California coast (Table 3). The latter must be viewed with caution, however, since it is not yet possible to eliminate the possibility of contamination during the collection of zooplankton fecal pellets. In addition, mineral content varies greatly among plankton species and within species in different geographical areas (Mayzaud and Martin, 1975).

Recent studies also suggest that the chemical composition of the blacksmith food varies to some extent on a seasonal basis (Escandon and Bray, unpubl.). However, unlike other vectors of mineral flux described to date, blacksmith fecal pellet deposition is predictable in time and space due to the daily homing and defecation pattern displayed by the fish (Bray et al., 1981).

Long term in situ incubation resulted in little dissolution of the fecal pellets when they were protected from scavenging organisms. These observations are consistent with the fact that although large numbers of bacteria were recovered from the feces, they exhibited very little activity based on the relatively constant cell densities and $\mathrm{P}$ concentrations. These results are supported by recent evidence that in nature, fecal pellet microbial populations are largely dormant (D. M. Karl, pers. comm.).

Pomeroy and Deibel (1980) found that, while bacterial densities were initially low in freshly collected feces of pelagic tunicates, a successsion of microbial populations occurred with subsequent incubation under laboratory conditions which indicated the presence of active bacteria. The cohesive nature of the fish fecal pellets indicated that they were surrounded by a peritrophic membrane which may have rendered them resistant to bacterial attack. It is unlikely therefore that dissolution through microbial action controlled the accumulation of the fecal pellets in the shelters. Current studies indicate that the fate of the fish feces may be determined by the foraging activities of reef detritivores (Rothans and Miller, unpubl.).

Although reliable data on the quantities of fecal material excreted by brown chromis in tropical reef shelters is as present not available, the lower fish densities (Bray et al., unpubl.) and smaller fish size indicate that their contribution to mineral flux is less than that of their temperate water counterpart. Unlike reefs off southern California, tropical reefs contain several species of fish which feed in the water column during the day and return to nocturnal shelters at night (Hobson, 1972). Thus, fish defecation may still repre- sent an important pathway of mineral importation to tropical reef communities despite the low contribution made by a single species.

Acknowledgements. We thank C. Kopczak, C. Norcross, G. Cailliet, M. Grober, and the Hydrolab crew for diving assistance, R. Given for logistic support, and A. Alldredge and G. Knauer for their critical review of the manuscript. This research was funded by a Faculty Research Fellowship from Associate Western Universities, Inc. to G.G.G., grant OCE8208215 from the Biological Oceanography Program of the National Science Foundation, and contract no. NA82 AAA 01465 from the National Oceanic and Atmospheric Administration, US Department of Commerce.

\section{LITERATURE CITED}

Alexander, G. V., McAnulty, L. T. (1981). Multielement analysis of plant-related tissues and fluids by optical emission spectrometry. J. Plant. Nutrit. 3: 51-59

American Public Health Association (1971). Standard methods for the examination of water and wastewater. Washington, D. C.

Atlas, R. M., Bartha, R. (1981). Microbial ecology. AddisonWesley Co., Reading, Mass.

Bishop, J. K. B., Edmonds, J. M., Ketten, D. R., Bascon, M. P., Silkers, W. B. (1977). The chemistry, biology, and vertical flux of particulate matter from the upper $400 \mathrm{~m}$ of the equatorial Atlantic Ocean. Deep Sea Res. 24: 511-548

Booth, P. A., Knauer, G. A. (1972). The possible importance of fecal material in the biological amplification of trace and heavy metals. Limnol. Oceanogr. 17: 270-274

Bray, R. N. (1981). Influence of water currents and zooplankton densities on the daily foraging movements of the blacksmith, Chromis punctipinnis, a planktivorous reef fish. Fish. Bull. U. S. 78: 829-841

Bray, R. N., Miller, A. C., Geesey, G. G. (1981). The fish connection: a trophic link between planktonic and rocky reef communities. Science, N. Y. 214: 204-205

Bruland, K. W., Silver, M. W. (1981). Sinking rates of fecal pellets from gelatinous zooplankton (salps, pteropods, diololids). Mar. Biol. 63: 295-300

Copin-Montegut, C., Copin-Montegut, G. (1978). The chemistry of particulate matter from the south Indian and Antarctic Oceans. Deep Sea Res. 25: 911-931

Dunbar, R. B., Berger, W. H. (1981). Fecal pellet flux to modern bottom sediment of Santa Barbara Basin (California) based on sediment trapping. Geol. Soc. Am. Bull. 92: $212-218$

Fliermans, C. B., Gordon, R. W. (1977). Modification of membrane diffusion chambers for deep-water studies. Appl environ. Microbiol. 33: 207-210

Fowler, S. W (1977). Trace elements in zooplankton particulate products. Nature, Lond. 269: 51-53

Hamner, R. M. (1981). Day-night differences in the emergence of demersal zooplankton from a sand substrate in a kelp forest. Mar. Biol. 62: 275-280

Hobson, E. S. (1972). Activity of Hawaiian reef fishes during the evening and morning transitions between daylight and darkness. Fish. Bull. U. S. 70: 715-740

Hobson, E. S., Chess, J. R. (1976). Trophic interactions among fishes and zooplankters nearshore at Santa Catalina Island, California. Fish. Bull. U. S. 74: 567-598

Johannes, R. E., Satomi, M. (1966). Composition and nutritive 
value of fecal pellets of a marine crustacean. Limnol Oceanogr. 11: 191-197

Knauer, G. A., Martin, J. H., Bruland, K. W. (1979). Fluxes of particulate carbon, nitrogen, and phosphorus in the upper water column of the northeast Pacific. Deep Sea Res. 26: $97-108$

Lal, D. (1977). The oceanic microcosm of particles. Science, N. Y. 198: 997-1009

Lisitzin, A. P., Belyaev, I., Bogdanov, Y. A., Bogoyavlensky A. W. (1966). Regularities in the distribution and forms of silica suspended in the waters of the world's oceans. In: Strakhov, N. M. (ed.) Geochemistry of silica. Nauka, p. 37-89 (cited in Copin-Montegut and Copin Montegut, 1978)

Madin, L. P. (1982). Production, composition, and sedimentation of salp fecal pellets in oceanic waters. Mar. Biol. 67 : $39-45$

Martin, J. H., Knauer, G. A. (1973). The elemental composition of plankton. Geochim. cosmochim. Acta 37: 1639-1653

Mayzaud, F. T., Martin, J. L. (1975). Some aspects of the biochemical and mineral composition of marine plankton. J. exp. mar. Biol. Ecol. 17: 297-310
Menzel, D. W., Goering, J. J. (1966). The distribution of organic detritus in the ocean. Limnol. Oceanogr. 11: 333-337

Mertz, W. (1981). The essential trace elements. Science, N. Y 213: $1332-1338$

Pomeroy, L. R., Deibel, D. (1980). Aggregation of organic matter by pelagic tunicates. Limnol. Oceanogr. 24: $643-652$

Robertson, D. R. (1982). Fish feces as fish food on a Pacific coral reef. Mar. Ecol. Prog. Ser. 7: 253-265

Robison, B. H., Bailey, T. G. (1981). Sinking rates and dissolution of midwater fish fecal matter. Mar. Biol. 65: 135-142

Ruby, E. G., Morin, J. G. (1979). Luminous enteric bacteria of marine fishes: a study of their distribution, densities, and dispersion. Appl. environ. Microbiol. 38: 406-411

Small, L. F., Fowler, S. W. (1973). Turnover and vertical transport of zinc by the euphausiid Meganyctiphanes norvegica in the Ligurian Sea. Mar. Biol. 18: 284-290

Unere, M. A., Knauer, G. A. (1981). Zooplankton fecal pellet fluxes and vertical transport of particulate organic material in the pelagic environment. J. Plankton Res. 3: $369-387$

This paper was presented by Professor R. Y. Morita; it was accepted for printing on September 27, 1983 